\title{
Coherence and Awareness among Young People from Quilombo do Areal
}

\author{
Dóris Cristina Gedrat ${ }^{1}$, André Guirland Vieira ${ }^{2}$, Cláudio Schubert ${ }^{3}$ \\ ${ }^{1} \mathrm{PhD}$ in Applied Linguistics, Professor of the Postgraduate Program in Health Promotion at the Lutheran University \\ of Brazil \\ ${ }^{2}$ Post-Doctorate from the Faculty of Psychology and Educational Sciences of the University of Porto (FPCEUP) - \\ Portugal. PhD in Developmental Psychology, Professor of the Postgraduate Program in Health Promotion at the \\ Lutheran University of Brazil \\ ${ }^{3} \mathrm{PhD}$ in Education, Professor of the Postgraduate Program in Health Promotion at the Lutheran University of Brazil \\ Correspondence: Dóris Cristina Gedrat, Postgraduate Program in Health Promotion, Universidade Luterana do Brasil, \\ 8001, Farroupilha Av., Canoas, RS, Brazil.
}

Received: September 2, 2019

Accepted: October 8, $2019 \quad$ Online Published: October 15, 2019

doi:10.5430/elr.v8n4p18

URL: https://doi.org/10.5430/elr.v8n4p18

\begin{abstract}
The objective of this study is to identify and assess coherence in the narratives produced by young residents of quilombo, who participated in an intervention study that aimed to empower them to deal with negative experiences in a positive way. A focus group intervention method was applied with 10 young individuals aged from 14 to 18 years who lived in Areal Quilombo in Porto Alegre, RS. They were asked to produce autobiographical or fictitious stories that pictured the daily life of a young resident of a quilombo. Eight narratives were recorded and filmed with the theme racial prejudice and discrimination. The stories' global coherence was assessed, and the presence of the Other in the I also investigated. Among the most meaningful results is that there is a change in the attitude toward racial prejudice when the prejudiced victim takes action in favor of this change and the self's property of being a multiplicity instead of a unity is confirmed.
\end{abstract}

Keywords: narratives, resilience, ethnic groups, risk groups, empowerment for health

\section{Introduction}

The notion of the narrative self was most recently developed by Dan McAdams (2001) using the concept of Narrative Identity. His starting point was Erikson's (1968) proposition that the development of a life story is a milestone in the process of acquiring a mature psycho-social identity. Adolescence is the moment of human development when the cognitive skills built throughout childhood to construct a coherent autobiographical narrative (Fivush, 2008) and sociocultural demands of a position within society (Erikson, 1968; Habermas, 2007) converge, culminating in the necessity and possibility of building a socio-culturally situated identity.

Aligned with the concept of anthology, beyond life stories and autobiographical narratives, our identity is also built on the stories others tell about us (Rosa \& Gonçalves, 2010; Pasupathi, 2001); the stories, books, and movies we read and watch; and the stories we imagine about the people around us (Hermans, 2007). Therefore, whether in the form of people or cultural products, others are introjected into our own identity. Each of us then establishes imaginary dialogues with these characters, which influences our process of understanding and gives significance to the world, creating a multifaceted self. This other in the self is often organized as the narratives-myths, dramas, comedies, television programs, etc. - we use as tools to produce our own understanding of the world including our lives. Sarbin (1990) called this phenomenon the Don Quixote principle. He refers to the famous Spanish hero who before calling himself Don Quixote, was the solitary nobleman Alonso Quesada, an avid reader of tales of chivalry who gradually shifted from spectator to actor until assuming the position of knight errant. Sarbin (1990) and Hermans (2007) contend that we live in a web of stories, some fictional, some not, where all shape our identity to some extent.

As Linde (1993) so well puts it, the narrative of life not only reveals the story of its author, but also the details of his personality, way of thinking and seeing the world, and social and psycho-pathological situation. Mishler (2002) highlights the role of the narrative act in the reassignment of meaning to past events: 
The narrative act reassigns meaning to events in terms of their consequences, that is, in how the story develops and ends, and not in terms of its temporal place in the sequence of events. In other words, narrative time is central to the way a story is structured and understood, and temporal ordering is simply a strategy for organizing events into a plot (Mishler, 2002, p. 106).

According to Linde (1993), in the sense of social obligation, coherence is an obligatory property in a narrative. It does not belong to the text, but is created by the speaker and their interlocutor who have a duty to create it to make themselves appear like competent members of their culture. The author argues:

In addition to being a social requirement, adequate coherence is also a personal demand that we make of ourselves. Just as a life story as a social unit has some correspondence with a particular internal life story, so the coherence we produce for social consumption has a relationship with our individual desire to understand our life as coherent, as making sense, as the story of an appropriate person (Linde, 1993, p. 17).

Investigating the narrative organization of the resilient self in young people in socially vulnerable situations of abandonment and adoption, Fitzhardinge (2008) identified the organization of coherent narratives as a fundamental element in the construction of a resilient narrative self. Young people tended to construct life stories focused on the theme of attachment and interpersonal relationships, so that the presence of coherent narratives seemed to indicate they were managing to deal with traumatic and disruptive elements present in the situation of abandonment through a re-signification of adverse experiences. The resilient group narratives had three characteristics in common: the ability to reflect on oneself and others, feeling they could be active about their circumstances to influence their future, and recognizing the importance of interpersonal relationships. Fitzhardinge concludes that constructed life narratives underlie the sense of self and that making the difference in building a resilient self is less about adverse events and more about the way young people understood them.

Our research revealed the organization of coherent narratives as a fundamental element in the construction of a resilient narrative self in young people belonging to a quilombo. They also find themselves in a vulnerable situation for various reasons including that they are black and live in a place socially recognized as poor and a point of drug trafficking and theft. Because of this social identity, the quilombola population has suffered various forms of prejudice (Ramos, 1996).

The term "quilombo," based on the definition of the Conselho Ultramarino (Overseas Council) in times of slavery, was related to runaway slaves in locations where there were few black groups, relative geographic isolation, and particular housing types and food. However, is there a quilombo at the end of the twentieth century? Who are the quilombolas? How do we define their descendants and enable access to the constitutional rights granted to them? A contemporary quilombo does not end with a signature and registration in the notary office. Rather, it is a struggle against oppression. The right of land regulation provided for in the Constitution does not presuppose its rapid realization. The issue of the quilombola communities in Brazil needs further study, information, and historical visibility. One fundamental point is the recognition, self-definition, unity, and conquest of rights, which often means breaking with historically constructed stigmas and prejudices. It is not easy to identify yourself as black in a racist and prejudiced society, as while black people have been "freed" from the chain of slavery, they remain "imprisoned" in the chains of prejudice. This is noticeable in the speech of a descendant black who refers to himself as "dark skinned," having difficulty recognizing himself as black. In this sense, recognizing oneself as black also signifies a political act (Silva \& Silva, 2014).

Despite the colonial inheritance, which confers negative values on black identity, it has been positively modified as a result of political organization. This is evidenced by the growing number of self-defining communities officially requesting their recognition as quilombo descendants. Self-recognition as a quilombo descendant is part of a process of identity (re)construction that encompasses cultural, historical, territorial, and kinship bias (Silva \& Silva, 2014).

Based on this history and the current situation of the quilombos, it was considered pertinent to choose the group to be researched in this location. This was because of their vulnerability and because the identity of the adolescents and young people residing there is influenced by both the historical aspects related to the quilombo and prejudices that still exist in society today, which judges them as poor and often marginalizes them because they are black and live in a quilombo.

The ability to deal positively with suffering situations is related to coherence (Adler, Lodi-Smith, Philippe \& Houle, 
2016), well-being and resilience (McAdams \& McLean, 2013). The subject capable of organizing his or her story is also able to reflect on it and resignify it in order to become proactive in relation to the exclusionary determinants that affect his/her behavior, such as being black and quilombo resident.

The aim of this study was to identify and evaluate the coherence of the narratives of a group of young quilombolas and relate the scores to identity and resilience. Both biographical and fictional narratives produced by young people were studied to verify how coping mechanisms were constructed in situations of vulnerability. As mentioned, both real and autobiographical stories as well as imagined ones regulate our relationship with the world. Through them, we dialogue in our imagination with their characters (Hermans, 2007). In this research, some narratives are autobiographical, others not, although all were produced with the motivation of narrating stories that portrayed the daily life of a young quilombola. The coherence of the stories was evaluated according to Habermas and Diel's (2005) three-dimensional model of global coherence of life narratives. Dialogic identity was investigated according to Hermans and Kempen (1993) and Hermans (2008).

\section{Methodology}

Our study used action research (Tripp, 2005; Paulon, 2005) and adopted a focus group intervention model (Hassen, 2002; Gondim, Feitosa, \& Chaves, 2007). The project was inspired by the work of Fitzhardinge (2008), in which the author asked a group of teenagers to make a film about their own lives focusing on the experience of being adopted. The objective of the focus groups, as used by Fitzhardinge, was to provoke participants to reflect on their own condition and help them develop strategies to deal with the difficulties imposed by the adversities of the socio-cultural environment. The study was approved by the ethics committee of the Lutheran University of Brazil under protocol number (CAAE) 50793415.6.0000.5349.

From this perspective, we investigated a group of 10 adolescents and young adults aged between 14 and 18 years belonging to the Quilombo do Areal located in the central region of Porto Alegre, RS. The research took the form of a 90-minute weekly workshop, over a period of 9 months (March to December/2017). The group of adolescents was given the task of constructing narratives that represented facts and themes central to their life in the quilombo. During the weekly meetings, the young people narrated their stories individually or collaboratively. These were then annotated, filmed, and recorded. The participants were instructed to create a story about a young person like themselves living in the quilombo. The participants spontaneously produced 8 stories about their life in the Quilombo.

The meetings took place within the quilombo on the premises of its community and cultural association, where the group of young people and researchers occupied a spacious room with a large table surrounded by chairs. The narratives, which were produced by the adolescents were analyzed by the researchers using the two independent judges system, and the results were compared and discussed until they reached consensus. The analysis followed the three-dimensional model of global coherence of life narratives conceived by Habermas and Diel (2005), Habermas and Silveira (2008), and Habermas, Ehlert-Lerche, and Silveira (2009). Figure 1 shows the assessment scale (Habermas \& Diel, 2005).

Simultaneously, the polyphonic and dialogical character of the narrative self was investigated, which based on studies by Rosa and Gonçalves (2010), Pasupathi (2001), Hermans and Kempen (1993), and Hermans (2008), interferes with individuals' identity construction. As a last activity, after all eight collected stories were created, the researchers conducted an evaluation with the participants, during which the young people expressed their opinion about the experience proposed by this research and gave their impressions on how they now deal with racial prejudice after having created and narrated their stories. 
A - TEMPORAL COHERENCE

Three Dimensions of Global Coherence

$1-$ It is not recognizable when and in which sequence the events occurred.

3 - It is often not recognizable when and in which sequence the events occurred.

5 - It is usually recognizable when and in which sequence the events occurred.

7 - It is clearly recognizable when and in which sequence the events occurred.

\section{B - CAUSAL AND MOTIVATIONAL COHERENCE}

1 - There is no significant personality development, except for external changes.

3 - Significant personality change is scarcely recognizable, except in several places where there was a tendency for some personality development.

5 - Personality development is reasonably significant, although not comprehensive.

7 - In key events and occasions, personality development is significant.

\section{C - THEMATIC COHERENCE}

1 - Events follow each other in a totally disconnected thematic order.

3 - Events follow in a somewhat disconnected order, although from time to time the relationships between events are indicated.

5 - Events are in certain ways placed in relation to each other, but sometimes the relationships between them remain obscure.

7 - Events are placed in relation to each other, and there are natural transitions between them.

Figure 1. Three dimensions of global coherence (Source: Habermas \& Diel, 2005)

\section{Results and Discussion}

We collected eight stories created by the adolescents, which are showed in Table 1:

Table 1. Summary of the eight stories created by the adolescents that participated in this study

Story 1, "Disgusting": describes a black woman abandoned by a white lover after becoming pregnant. The daughter, brown skinned, rejects her mother for being black, saying she is disgusted with her.

Story 2, "Homemade pizza, bean stew, and polenta": addresses the conflicting relationship of a racist social worker with a black woman. The social worker reveals her racism after meeting the black woman at her mother's house, for whom she cooks.

Story 3 (untitled): is about a white man who decides to abandon his partner, a black woman, when she asks him for money to go to the supermarket.

Story 4 (untitled): tells of a black woman who is mistreated by a white shop assistant when she looks at a dress.

Story 5 (untitled): tells of a girl who is bullied at school for being black, which forces her to drop out.

Story 6 (untitled): tells of a white girl who falls in love with a black drug dealer living in the quilombo. She leaves her family and moves in with him when her parents discover the romance and forbid it.

Story 7 (untitled): is about the difficulty of a black boy entering a private school.

Story 8 (untitled): tells of a black woman who has several children and how she supports them. She marries a white man who does not want to have her children or raise them because they are not his color.

Source: The authors

Just as Fitzhardinge (2008) discovered among young adoptees, our research identified the organization of coherent narratives as a fundamental element in the construction of a resilient narrative self in young people belonging to the Quilombo do Areal. The theme of all the stories was the racial prejudice suffered in school and society, both because of skin color and the quilombola origin of the young people.

Among the eight stories, two are autobiographical, both related to prejudice suffered in school situations due to skin color. The others also address the issue of racial prejudice, but in different situations. As Table 2 shows, five stories had a low evaluation for causal coherence, while the others obtained the maximum score for this item. For temporal 
and thematic coherence, all stories obtained a maximum score. This led to a score of 15 in total for stories $1,3,4,6$, and 7, and 21 for stories 2, 5, and 8. The latter obtained the maximum for causal coherence, unlike the first group.

Table 3 shows the results focusing on overall story performance for each coherence item. Causal coherence scored lowest, with 26, while temporal and thematic coherence each scored 56 points.

Table 2. Individual dimensions of global coherence: Dimensions of global coherence by story (Scale from 1 to 7 )

Story 1
Temporal coherence -7
Causal coherence -1
Thematic Coherence -7
Total - 15

Story 3

Temporal coherence - 7

Causal coherence -1

Thematic coherence -7

Total - 15

Story 5 (autobiographical)

Temporal coherence - 7

Causal coherence - 7

Thematic Coherence - 7

Total - 21

Story 7 (autobiographical)

Temporal coherence - 7

Causal coherence - 1

Thematic coherence -7

Total - 15

\section{Story 2}

Temporal coherence - 7

Causal Coherence - 7

Thematic Coherence - 7

Total - 21

Story 4

Temporal coherence - 7

Causal coherence - 1

Thematic coherence -7

Total - 15

Story 6

Temporal coherence - 7

Causal coherence - 1

Thematic coherence -7

Total - 15

Story 8

Temporal coherence - 7

Causal coherence - 7

Thematic coherence -7

Total -21

Source: Habermas and Diel (2005)

Table 3. Overall dimensions of global coherence

\begin{tabular}{l|l}
\hline Overall dimensions of global coherence: (Scale from 8 to 56) \\
\hline Temporal coherence & 56 \\
\hline Causal coherence & 26 \\
\hline Thematic coherence & 56 \\
\hline
\end{tabular}

Source: Habermas and Diel (2005)

As mentioned, the present study analyzed narratives young people produced in relation to life in the quilombo. As the theme of all narratives was racial prejudice, the analysis focused on this issue. To assess the three dimensions of coherence by Habermas and Diel (2005), we considered the attitudes of all characters in each story, not just the narrator.

Relating the conclusions of these authors to the results obtained after analyzing the overall coherence of the narratives of the quilombo young people, the high score on temporal coherence, as per the methodological proposal of Habermas and Diehl (2005), signifies a great ability to locate a particular event in the context of an individual life. In each narrative, it is clearly recognizable when and in which sequence the events occurred. Therefore, we observed a clear and objective awareness of events related to the lives of black people in different situations involving white people and how quilombo residents are treated by others, not necessarily only those who are white. 
For causal and motivational coherence, the score was relatively low. According to the principles of Habermas and Diel (2005), this signifies little awareness of the causes and consequences of their actions, since little or no significant development of the personality of the story participants was found for stories with low scores for this item, namely $1,3,4,6$, and 7 . The others-2, 5, and 8-received the highest score for this type of coherence. First, both the causes and consequences of the actions of black participants in the stories relate to the fact that they are black, not to their specific attitudes, according to the young people who narrated them. For them, skin color is the reason for everything: that which keeps a girl from marrying and being happy with a white man, a student entering a private school, a student easily integrating into group activities in the classroom, a mother to be recognized by her daughter as such, or a young man to be welcomed by his girlfriend's parents.

Furthermore, the fact that in some stories there has been significant personality development of one or more characters in relation to prejudice with noticeable behavioral changes is very important in relation to the evaluation criteria of Habermas and Diel (2005). In story 2, the social worker, averse to the presence of a black woman working at her mother's house, repeatedly praises the food served by her mother knowing it was made by the black woman. However, she then starts to admire the woman's skills and personality and changes her negative attitude toward her. Story 5 also develops in this sense, with a change in the way the black student, a victim of racial prejudice at school, is treated. However, the change also coincides with the transfer of the student to a new school, and therefore, to her insertion in a new class with a new teacher. Story 8 is the third story to present an attitude change toward black people. Here, the white man married to a black woman, who already has children from other relationships, does not want to contribute to supporting her children because of their skin color. As a result, the woman leaves him and prioritizes her children. He then begins a romance with a white woman, who on becoming aware of the situation, rejects him, saying he should apologize to the woman and her children and that she does not want a relationship with someone who acts like this with his partner.

A clear intervention on the part of black victims of prejudice, or their parents or guardians was observed in the three stories with personality development. This also led the white characters to move toward combating prejudice and contempt for blacks. The social worker in story 2 came to admire and value the black woman for her culinary skills. The ability shown by the black person leads to her respect. In story 5, the mother of the black student who suffers racial prejudice at school transfers her daughter to another school after unsuccessfully attempting to change the situation by talking to the school leaders. She justifies the transfer and obtains the support of the directors and new teacher, who influences the students to have an ethical attitude toward the black student. Finally, in story 8, the black mother takes an assertive attitude by not accepting that her children are scorned, opting for them and not for a relationship that excludes them. Then, the white man's new partner, who is white, supports her, refusing a relationship with someone who dislikes blacks and treats a partner with contempt.

The high score for the thematic coherence of the eight stories, according to the dimensions of individual global coherence of Habermas and Diel (2005), demonstrates insight regarding the degree of stability of facts along the trajectory of each story. This indicates that events are placed relative to each other and that there are natural transitions between them. All research participants share the same core characteristics that define them as a group - being black and living in the quilombo. For them all, a stable fact throughout their and their families' lives is the prejudice faced in society because of these conditions. It was observed in the testimonies given in the evaluation (Figure 2) that requesting the young people to tell their stories gave them the opportunity to recount their experiences and allay their emotions related to this theme. This helped them feel free to express themselves in front of other people, both on prejudice and other subjects related to classroom studies and activities.

As established, Hermans (2007) states that the stories we tell, both real and imagined, regulate our relationship with the world, and through them we develop imaginary dialogues with their characters and specific scenarios. A complex and well-structured narrative self is capable of imaginatively endowing each position with a voice in a way that allows establishing dialogical relationships between positions. It was observed in the young people's stories that this dialogue exists and occurs naturally. The young people created their stories with ease and speed, without any difficulty in deferring the outcome until the end. This reveals a well-structured narrative self, as Hermans (2008) proposed: "As long as there is dialogue between the positions of the I, the self will remain integrated with a sense of unity and the personality will remain organized" (p. 188).

The multifaceted characteristic of the self referred to by Hermans and Kempen (1993) was also noticed in the stories produced. Hermans (2008) highlights the self as a myriad of things and not just a single unit. It is possible to identify different voices corresponding to the different positions taken by the "I" of the narrators and dialogical relationship between them. Here, the young people are establishing imaginary dialogues with the characters that integrate their 
identity, which influences their process of understanding and gives meaning to the world (Hermans \& Kempen, 1993).

This is displayed when a young black man from the quilombo tells a story in which a white social worker does not sympathize with her mother's black maid. Even for a social worker, where solidarity and spirit of inclusion are fundamental, in her personal life she maintains a despicable attitude toward black people. The narrator of this story establishes an inner dialogue arising from situations he experiences or knows, which is identified in a story he creates to narrate.

The same happens when narrating "Disgusting," a story formulated in a group of young people. In this story, the presence of imaginary characters is clear, but these are anchored in the reality lived by the quilombolas. A black mother is a source of shame to a daughter whose father is white. The value of the mother loses strength, because the girl has a chance to belong to whites through her father, which makes her feel superior and despise her mother, who keeps herself among black people.

\section{Testimonials of the young people at the end of their storytelling experience:}

a. "I think (...) everyone learned to defend themselves more, everyone learned to speak. It is not that you are not ashamed, but you go on the street, you swear at anyone, you tell everyone off. So, I think it helped everyone here a lot (...) to impose themselves on the world, on what is wrong and what is right. It helped everyone to understand what is right and what is wrong and to give an opinion, so it is helping everyone to... grow, right?"

b. "X would not open her mouth for anything, now you say something to $\mathrm{X}$ she will tell you where to go" (referring to a young woman who never expressed herself).

c. "I lost the shame of talking in front of the camera a little bit, because before I froze."

d. "Speaking of losing the shame, I do not know many people (...) I was ashamed to talk to her and I lost the shame of talking to her (referring to people)."

e. "I am a person who when it comes to prejudice (...), like to talk, because I already suffered from it, so I think I already have an opinion about why I was already the target of prejudice (...). Also because of living in the quilombo (...). I need to talk about what is inside me (...)." f. "If you argued at school about prejudice and had to write an essay and got a high score, it was progress to say you learned it here."

g. "It seems that when we started here, this subject exploded in the classroom."

h. "It has been good, because we will take this to the rest of our life, you understand (...). For me, it has been very important, because I don't know, last year I had a lot of shame. I did not want to talk in front of anyone, (...) and not now."

i. "I go to the front (present work in class), first I breathe (...) (people) talk to me normally, say hi to me..."

j. "I solved my shame, I solved my posture (...) I express myself much more (in the classroom)."

Figure 2. Testimonials collected in the evaluation from the young people of the quilombo

Finally, important conclusions were drawn from the participants' evaluation of the storytelling activities that portrayed daily life in the quilombo. The statements transcribed in Figure 2 indicate that the intervention helped them cope with the adversities experienced in their daily lives with more energy and confidence. They were also able to work more easily in ordinary situations, especially those related to the classroom, and thus increased their resilience in the face of difficulties and challenges. Here, we visualize a connection with the notion that Mishler (2002) presents as "turning points." 
Turning points are often sudden and unexpected incidents that can change the understanding of past experiences. The process of re-history, which is marked by and results from these important turning point incidents, is a general feature of the multiple identities of each person rooted in a different set of relationships that form their life matrix. Each of one's partial selves is a character in a different story, in which that person is positioned in different ways in her relationships with others. These constitute a person's various social worlds. According to the author, a turning point may mean individuals' new attitude toward adverse situations, leading them to build a life story in which such situations, which once dominated and caused them suffering, are no longer a threat or can be overcome.

This present intervention in the quilombo may have been a turning point in the lives of these young people, because through the opportunity to tell the facts related to the racial prejudice experienced in their daily lives, they acquired new ways of facing such situations and were often able to overcome them, as indicated in the testimonials in Figure 2. These activities, which for the young people were a sudden and unplanned event, may have led them to intensify their empowerment and autonomization process to build their black identity and fight against prejudice.

\section{Final Considerations}

The results obtained in this intervention research allow us to draw conclusions based on the analysis of the quilombo young people's narratives. The results of the evaluation demonstrate the construction of narratives and behavioral attitudes during meetings and the existence of a process of awareness toward emancipating attitudes. A first step to empowerment is the notion that "I can do it, I am capable, I have the potential to... as many other people do." This is a behavior contrary to the victimization often present in peripheral social groups. For example, this is illustrated in the evaluation of speaker $\mathrm{g}$ in Figure 2: "It seems that when we started here, this subject exploded in the classroom." This refers to the prejudices embodied in attitudes within the classroom. The topic has always been on the agenda in the classroom, but the awareness and empowerment to perceive and participate in this discussion only becomes possible when someone ceases to be anonymous, when they move from being voiceless to having an active purposeful attitude, breaking the silence and using the word as a means of emancipation and empowerment.

According to Baerger and McAdams (1999) and Adler, Wagner, and McAdams (2007), an autobiographical production implies the narrative reconstruction of past events and the historical process itself. This produces a re-signification of the past that is capable of reorganizing traumatic experiences and conferring a new meaning on them. We sought to break with a certain "vicious circle" present in the Brazilian culture (Holanda, 1995), where proactivity, initiative, and the achievement of personal and professional ideals are easily replaced by the feeling of incapacity, a lack of initiative, and low self-esteem.

We hope to have contributed to a re-signification of what the young people of the quilombo have experienced from an early age, where they are considered less competent and respectable by their peers, teachers, and other staff members in their school. May this lead to a rethinking of their own existence and empower an awareness of their potential and right to live and be citizens.

\section{References}

Adler, J. M., Lodi-Smith, J., Philippe, F. L., \& Houle, I. (2016). The incremental validity of narrative identity in predicting well-being: A review of the field and recommendations for the future. Personal and Social Psychology Review, 20(2), 142-175. https://doi.org/10.1177/1088868315585068

Adler, J. R., Wagner, J. W., \& McAdams, D. P. (2007). Personality and the coherence of psychotherapy narratives. Journal of Research in Personality, 41, 1179-1198. https://doi.org/10.1016/j.jrp.2007.02.006

Baerger, D. R., \& McAdams, D. P. (1999). Life story coherence and its relation to psychological well-being. Narrative Inquiry, 9, 69-96. https://doi.org/10.1075/ni.9.1.05bae

Erikson, E. H. (1968). Youth and identity. New York: Norton.

Fitzhardinge, H. (2008). Adoption, resilience and the importance of stories. Adoption and Fostering, 32(1), 58-68. https://doi.org/10.1177/030857590803200108

Fivush, R. (2008). Remembering and reminiscing: How individual lives are constructed in family narratives. Memory Studies, 1(1), 49-58. https://doi.org/10.1177/1750698007083888

Gondim, S. M. G., Feitosa, G. N., \& Chaves, M. C. (2007). A imagem do trabalho: um estudo qualitativo usando fotografia em grupos focais. $R A C, 11(4), 153-174$. https://doi.org/10.1590/S1415-65552007000400008

Habermas, T. (2007). How to tell a life: The development of the cultural concept of biography. Journal of Cognition and Development, 8(1), 1-31. https://doi.org/10.1080/15248370709336991 
Habermas, T., \& Diehl, V. (2005). Three dimensions of global coherence: Global rating scales. Frankfurt: Goethe University.

Habermas, T., \& Silveira, C. (2008). The development of global coherence in life narratives across adolescence: temporal, causal and thematic aspects. Developmental Psychology, 44, 707-721. https://doi.org/10.1037/0012-1649.44.3.707

Habermas, T., Ehlert-Lerche, S., \& Silveira, C. (2009). The development of the temporal macro-structure of life narratives across adolescence: Beginnings, linear narrative form, and endings. Journal of Personality, 77(2), 527-559. https://doi.org/10.1111/j.1467-6494.2008.00557.x

Hassen, M. N. A. (2002). Grupos focais de intervenção no projeto sexualidade e intervenção. Horizontes Antropológicos, 8(17), 159-177. https://doi.org/10.1590/S0104-71832002000100009

Hermans, H. J. M. (2007). A pessoa como narrador motivado de histórias. In Miguel M. Gonçalves e Óscar F. Gonçalves (org.), Psicoterapia, discurso e narrativa: a construção conversacional da mudança (pp. 157-207). Coimbra: Ed. Quarteto.

Hermans, H. J. M. (2008). How to perform research on the basis of dialogical self theory? Introduction to special issue. Journal of Constructivist Psychology, 21, 185-199. https://doi.org/10.1080/10720530802070684

Hermans, H. J. M., \& Kempen, H. J. G. (1993). Imaginal dialogues in the self: Theory and method. Journal of Personality, 61(2), 207-236. https://doi.org/10.1111/j.1467-6494.1993.tb01032.x

Holanda, S. B. (1995). Raízes do Brasil. 26 ed. São Paulo: Cia de Letras.

Linde, C. (1993). Life Stories: the creation of coherence. New York: Oxford University Press.

McAdams, D. P. (2001). The psychology of life stories. Review of General Psychology, 5(2), 100-122. https://doi.org/10.1037/1089-2680.5.2.100

McAdams, D. P., \& McLean, K. C. (2013). Narrative identity. Current Directions on Psychological Science, 22(3), 233-238. https://doi.org/10.1177/0963721413475622

Mishler, E. G. (2002). Narrativa e identidade: a mão dupla do tempo. In Luiz Paulo da Moita Lopes \& Liliana Cabral Bastos. (Eds.), Identidades: Recortes multi e interdisciplinares. Campinas: Mercado de Letras.

Pasupathi, M. (2001). The social construction of the personal past and its implications for adult development. Psychological Bulletin, 127(5), 651-672. https://doi.org/10.1037/0033-2909.127.5.651

Paulon, S. M. (2005). A análise de implicação como ferramenta na pesquisa-intervenção. Psicologia e Sociedade, 17(3), 18-25. https://doi.org/10.1590/S0102-71822005000300003

Ramos, D. (1996). O quilombo e o sistema escravista em Minas Gerais no século XVIII. In J. J. Reis \& F. S. Gomes (Org.). Liberdade por um fio: história dos quilombos no Brasil. São Paulo: Companhia das Letras.

Rosa, C., \& Gonçalves, M. (2010). Um olhar empírico sobre a identidade dialógica: Um estudo sobre a conjugalidade. Psychologica, 53, 81-108. https://doi.org/10.14195/1647-8606_53_5

Sarbin, T. R. (1990). The narrative quality of action. Theoretical and philosophical psychology, 10, 49-65. https://doi.org/10.1037/h0091497

Silva, G. S., \& Silva, V. J. (2014). Quilombos brasileiros: alguns aspectos da trajetória do negro no Brasil. Revista Mosaico, 7(2), 191-200.

Tripp, D. (2005). Pesquisa-ação: uma introdução metodológica. Educação e pesquisa, 31(3), 443-466. https://doi.org/10.1590/S1517-97022005000300009 